\title{
Green tea glycolic extract-loaded liquid crystal systems: development, characterization and microbiological control
}

\author{
Jéssica Bernegossi' ${ }^{1}$, Raquel Maria Cunha Barbosa², Patrícia Maciel Rustice², Marlus Chorilli ${ }^{*}$
}

${ }^{1}$ São Paulo State University, School of Pharmaceutical Sciences, Department of Drugs and Medicines, Araraquara, São Paulo, ${ }^{2}$ Pontificia Universidade Católica de Campinas, Campinas, São Paulo, Brazil

\begin{abstract}
Liquid crystal systems (LCSs) have interesting cosmetic applications because of their ability to increase the therapeutic efficiency and solubility of active ingredients. The aim of the present research was to develop green tea glycolic extract-loaded LCSs, to characterize and to perform microbiological control. The ternary phase diagram was constructed using polysorbate 20 , silicone glycol copolymer (SGC) DC $193^{\circledR}$, and distilled water with $1.5 \%$ glycolic green tea extract. The systems were characterized by polarized light microscopy. Formulations selected were characterized as transparent viscous systems and transparent liquid system indicated mesophases lamellar structure. The results of the microbiological analysis of mesophilic aerobic microorganisms (bacteria and fungi) revealed that the above formulation showed a biologic load $<10 \mathrm{CFU} / \mathrm{mL}$ in all samples. In conclusion, liquid crystalline systems that have presented formation of a lamellar mesophases were developed. Furthermore, the formulation and products tested presented the adequate microbiological quality in accordance with official recommendations.
\end{abstract}

Uniterms: Camellia sinensis/glycolic extract. Liquid crystal systems/cosmetic applications. Liquid crystal systems/characterization. Liquid crystal systems/microbiological control.

\section{INTRODUCTION}

Technological developments in the cosmetics industry and improved understanding of skin physiology have led to the incorporation of several active substances that are now commonly used in cosmetic formulations. Plant extracts, especially green tea glycolic extract, have been recently proposed for different purposes (Gianeti et al, 2013).

Green tea, obtained from the plant Camellia sinensis, is rich in polyphenols, such as catechins. The most active catechin seems to be 3-gallate (-) epigallocatechin. Clinical studies show that green tea acts as a chemoprotectant and sunscreen agent with activities such as antioxidant, free radical scavenging, inhibiting the induction, initiation, promotion, and proliferation of carcinogenesis, antiinflammatory, antiangiogenic, inducer of apoptosis of carcinogen cells, metalloproteinase inhibitor, protector of the conversion of benign cells into malignant, and inhibitor

*Correspondence: M. Chorilli. Departamento de Fármacos e Medicamentos. Faculdade de Ciências Farmacêuticas. Universidade Estadual Paulista - UNESP. Rodovia Araraquara-Jaú, Km 1, 14800-903 - Araraquara - SP, Brasil. Email: chorilli@fcfar.unesp.br. Phone: +55 1633016961 / Fax: +55 1633016960 of DNA damage (Pereira et al., 2009; Yun, Yang, 2015; Rodrigues et al., 2016).

Studies performed by our research group compared pomegranate and green tea glycolic extracts (GTGE) in formulations and concluded that GTGE possessed greater bacterial growth inhibition measured as zone of inhibition than the other extracts, suggesting that GTGE has high antibacterial activity (Calixto et al., 2012).

With the aim of obtaining final products with real benefits that can be perceived by consumers and to optimize the sensory attributes of these formulations, researchers have resorted to theories and scientific experimentations that were unique to the development of pharmaceutical preparations. Active substance delivery systems that were previously developed for pharmaceutical products (e.g., micro- and nanoemulsions and liquid-crystalline systems) are currently of interest to formulators of cosmetic products because they facilitate the diffusion of active compounds, increase stability, reduce side effects, can increase the effectiveness of the formulation, and improve the appearance of the final product (Hosmer et al., 2009).

Liquid crystal systems (LCSs) present 
mechanical characteristics of a liquid (fluidity) and optical characteristics of a solid crystal (optical anisotropy). They are thermodynamically stable and can be classified as either thermotropic or lyotropic systems. Thermotropics are formed by arrangement of individual molecules (pure substances) and lyotropics, by micelles (surfactants mixed with a solvent, usually water) (Aouada et al., 2006; Chorilli et al., 2009; Prestes et al., 2010; Chorilli et al., 2011; Calixto et al., 2014; Oyafuso et al., 2015). It is well known that surfactants tend to spontaneously self-associate and can form highly ordered aggregates, such as lamellar, hexagonal, and cubic liquid crystalline phases, at higher concentrations (Fraser et al., 2009; Calixto et al., 2014).

LCSs promote the controlled release of active substances and the active components are embedded in arrays of liquid crystals or formulations containing them. They also offer some protection against photo- or thermal degradation and can promote increased water retention in the stratum corneum, providing increased skin hydration. Finally, LCSs promote the sustained release of active substances and physicochemical stability of emulsions (Formariz et al., 2005; Santos, Rocha Filho, 2007).

Liquid crystals are not generally employed in formulations of microbiological preservatives because they have large amounts of surfactants that suppress the growth of micro-organisms. Moreover, the high concentration of oil limits water access, which is one of the main causes of antimicrobial action (Oliveira et al., 2007).

Thus, considering that such systems generally do not contain preservatives, it is extremely important to control microbiological growth to ensure a good quality product that is free of potentially harmful microorganisms and to ensure stability even after continuous use by the consumer (Oliveira et al., 2007).

Studying the stability of cosmetic formulations is important because it provides indications about the behavior of the product at any given time interval compared to the environmental conditions that can be submitted from manufacturing until the expiration date. These studies help to guide the development of appropriate formulation and packaging materials and provide support for improved formulations. Furthermore, these studies can estimate the shelf life of a product, assist in monitoring the organoleptic, physicochemical, and microbiological stabilities, and provide information about the reliability and safety of products (Prestes et al., 2010; ANVISA, 2004).

The aim of the present research was to develop and characterize microbiological control of green tea glycolic extract-loaded LCSs.

\section{METHODOLOGY}

\section{Characterization of the green tea glycolic extracts}

The evaluation of the presence of phytochemical classes was performed using methodologies already established in the scientific community (Glory et al., 2016).

In the Shinoda's reaction was added to $3 \mathrm{~mL}$ of the extract, $1 \mathrm{~mL}$ of $\mathrm{HCl}$, and two fragments of magnesium for the detection of flavonoids. The compounds were characterized by the alpha-benzopyrone core changing from orange to red.

Ferric chloride was added to $3 \mathrm{~mL}$ of glycolic extract by adding drop of ferric chloride until a final concentration of $4.5 \%$. Ferric chloride (oxidizer) is used to characterize polyphenols in general, reducing substances that are easily oxidized and staining generated products. Positive staining is evidenced by a blue or bluegreen color change.

Sodium hydroxide $(\mathrm{NaOH})$ solution was added to $3 \mathrm{~mL}$ of extract glycolic solution. The solution acquires a yellowish color in the presence of the chromone central nucleus or in the presence of a hydroxyl attached to aromatic rings.

To react with the iron salts, $1 \mathrm{~mL}$ of the extraction solution was combined with $10 \mathrm{~mL}$ of water and a drop of ferric alum solution to a final concentration of $1 \%$. The development of a blue color indicates the presence of hydrolysable tannins that reacted with ferric chloride.

$10 \mathrm{~mL}$ of acetic acid to $10 \%$ and $5 \mathrm{~mL}$ of lead acetate to $10 \%$ were added in $5 \mathrm{~mL}$ of glycolic extract. The precipitate is formed in the presence of tannin branches. The acetic acid retains the dissolved catechin-tannins and prevents its precipitation (Simões, 2003).

\section{Development of formulations}

The ternary phase diagram was constructed by preparing formulations using polysorbate 20 (surfactant), SGC (DC $193^{\circledR}$ ) (oil phase), and distillate water plus GTGE $1.5 \%$ (aqueous phase). The systems were heated in thermostatic water bath at $45^{\circ} \mathrm{C}$ to promote full homogenization. After twenty four hours of stabilization, the consistency and aspect of formulations were visually verified against a dark background to limit the areas of the different systems formation in a transparent liquid system (TLS), cloudy liquid system (CLS), transparent viscous system (TVS), and phase separation (PS). 


\section{Polarized light microscopy}

Only transparent formulations were investigated further for the presence of liquid crystal. This investigation was performed using polarized light microscopy (PLM) with a Motic BA400 Type 102 microscope at room temperature $\left(25 \pm 1{ }^{\circ} \mathrm{C}\right.$ ) (Bernegossi et al., 2016).

\section{Microbiological quality control}

Salmonella spp. (ATCC 19196), Staphylococcus aureus (ATCC 25923), Pseudomonas aeruginosa (ATCC 27853), and Escherichia coli (ATCC 25922) were counted along with the total viable aerobic microorganisms to estimate the mesophile aerobic microorganisms present in the samples (Oliveira et al., 2013; Koneman et al., 2001; USP, 2008). The presence of these microorganisms indicates microbial contamination in pharmaceutical and cosmetic finished products and can cause physical changes in the formulation (Oliveira et al., 2013; Shaikh, Jamshed, Shaikh, 1988).

Aliquots of the formulations were transferred to specific culture environments to determine the total number of microorganisms and the presence of the previously mentioned bacteria. In these analyses, representative samples of the product content were analyzed in accordance with methods recommended by the United States Pharmacopeia (USP, 2008). The analyses were made in triplicates for each formulation. The formulations subject to microbiological control were stored in aseptically clean containers, far from humidity and light, in cool and aired places, according to the Brazilian Pharmacopoeia (Oliveira et al., 2013; Brazilian Pharmacopoeia, 2010; USP, 2008).

\section{Estimating the number of viable microorganisms}

Viable fungal and mesophilic bacteria in the formulas were determined by the pour-plate method. Small aliquots $(1 \mathrm{~mL})$ of 1:10 and 1:100 dilutions of the product in a saline solution were transferred to two series of Petri dishes in triplicate. The first set was homogenized with $15 \mathrm{~mL}$ of Tryptone Soya Agar (TSA) and the other with $15 \mathrm{~mL}$ of Sabouraud Dextrose Agar (SDA) (Difco ${ }^{\circledR}$ ). Plates were incubated at $22 \pm 2.5^{\circ} \mathrm{C}$ and $32 \pm$ $2.5^{\circ} \mathrm{C}$ for fungi and bacteria, respectively. The colonies grown in these cultures were counted and the number of micro-organisms per gram of the product, expressed in colony-forming units per gram (CFU/g) (Oliveira et al., 2013; USP, 2008).

\section{Validation of the method for estimating the number of viable microorganisms}

Salmonella spp., S. aureus, P. aeruginosa, E. coli, Candida albicans, and Aspergillus niger were analyzed. For this, $1 \mathrm{~mL}$ aliquots of $1: 2$ and 1:10 dilutions of the formulations in a sterile saline solution and $0.5 \mathrm{~mL}$ of the microbial suspension (containing less than 100 CFU) were transferred to Petri dishes. The aliquots of these formulations were mixed with $15 \mathrm{~mL}$ of TSA. The assay sequence was the same as the one described for determining viable micro-organisms. The control assays were also performed in parallel by transferring $0.5 \mathrm{~mL}$ of each microbial suspension to Petri dishes using 15 mL of TSA (Bou-Chacra et al., 2005). Petri dishes were incubated at $32 \pm 2.5^{\circ} \mathrm{C}$ and $22 \pm 2.5^{\circ} \mathrm{C}$ for bacteria and fungi, respectively. This assay was performed in triplicate (Oliveira et al., 2013).

\section{Research of Salmonella spp. and E. coli}

Ten grams of sample were transferred to $90 \mathrm{~mL}$ of lactose broth to analyze Salmonella spp. and E. coli. The culture was incubated at $36 \pm 1{ }^{\circ} \mathrm{C}$ for 24 hours. The growth of the culture was observed after this interval according to the following procedures.

Salmonella spp. growth analysis: $1 \mathrm{~mL}$ of lactose broth was transferred to Petri dishes containing tetrathionate broth base and selenite cystine enrichment broth. Plates were incubated at $36 \pm 1^{\circ} \mathrm{C}$ for 24 hours. After this period, samples of the tetrathionate broth base were transferred to Petri dishes containing brilliant green agar, xylose lysine desoxycholate agar (XLD), and bismuth sulfite agar. A similar procedure was followed for the sample inoculated in the selenite cystine enrichment broth. Plates were incubated at $36 \pm 1^{\circ} \mathrm{C}$ for 24 hours. The growth and characteristics of the colonies were observed. The suspicious colonies were sown with a straight handle in Petri dishes containing triple sugar iron agar (TSI) and incubated at $36 \pm 1{ }^{\circ} \mathrm{C}$ for 24 hours.

E. coli growth analysis: $1 \mathrm{~mL}$ of the lactose broth was added to Petri dishes containing MacConkey agar. Plates were incubated at $36 \pm 1{ }^{\circ} \mathrm{C}$ for 24 hours. The growth and characteristics of the colonies were observed. The suspicious colonies were sown with platinum handles in Petri dishes containing Levine EMB agar. Plates were incubated at $36 \pm 1{ }^{\circ} \mathrm{C}$ for 24 hours (Oliveira et al., 2013).

\section{Research of $S$. aureus and $P$. aeruginosa}

The samples (10 g) were transferred aseptically to 
$90 \mathrm{~mL}$ of tryptic soy broth to analyze the growth of $P$. aeruginosa and $S$. aureus. The broth was incubated at $36 \pm$ $1{ }^{\circ} \mathrm{C}$ for 24 hours. Bacterial growth was observed after this interval. S. aureus were sown on Petri dishes containing Vogel Johnson agar. $P$. aeruginosa were grown on Petri dishes of cetrimide agar. The plates were incubated at 36 $\pm 1{ }^{\circ} \mathrm{C}$ for 24 hours and the growth and characteristics of the colonies were observed (Oliveira et al., 2013).

\section{RESULTS AND DISCUSSION}

\section{Characterization of the green tea glycolic extracts}

The results of the phytochemical characterization of the GTGE were shown in Table I.

It is known that green tea is rich in antioxidants as flavonoids and tannins (Senger et al., 2010; Leão et al., 2016). Proving the presence of these compounds in commercial products should be a constant concern. As can be seen in Table I, the green tea glycolic extract showed positive results for flavonoids and tannins, testifying quality.

\section{Development of formulations}

It is extremely important to choose components that possess desired criteria, such as efficacy, safety, stability, and consumer acceptance, when developing new formulations. Raw materials are often available in large amounts to allow for good sensorial analysis and product stability (Ayannides, Ktistis, 2002).

In this study, formulations with high concentrations of surfactants were developed to achieve LCSs and to improve the efficacy of substance incorporation in the formulations. LCSs have been used to improve the solubility, bioavailability, and delivery of lipophilic and hydrophilic active ingredients (Massaro et al., 2003; Masson et al., 2005). It has been suggested that these systems also act as self-preserving antimicrobials (Vasconcelos, Medeiros, Nascimento, 2015).

The system developed comprised SGC - DC $193^{\circledR}$ as the oil phase, polysorbate 20 as surfactant, and distilled water with GTGE $1.5 \%$ as the aqueous phase. Silicones are increasingly used in cosmetics because of their many advantages, such as non-comedogenicity, film formation, skin hydration, good skin feel, and consumer acceptance. Thus, the association of liquid crystal and silicones will promote formulations that are more stable, efficient, penetrating, and retain skin moisture (Chorilli et al., 2009).

We observed TVS formation with relatively low oil concentration (10\%) and a $50 \%$ concentration of surfactant, thus fulfilling two important requirements, because high concentrations of surfactants can lead to skin irritation and many oils have comedogenic properties (Chorilli et al., 2016).

Figure 1 shows the pseudoternary phase diagram produced by the investigated system using SGC - DC $193^{\circledR}$, polysorbate 20 , and distilled water with GTGE $1.5 \%$.

TLSs were only obtained using $40-80 \%$ of the surfactant mixture (Figure 1). Gursoy and Benita (2004) reported that the surfactant concentration necessary to form stable LCSs usually ranges between 30-60\%.

In this study, we used polysorbate 20 because of its low toxicity and easy stabilization on droplets with small diameters (Bartůněk et al., 2015).

For the studies of PLM and microbiological quality control, we selected a region of TVS consisting of $50 \%$ of surfactant, $10 \%$ of SGC - DC $193^{\circledR}$, and $40 \%$ of the aqueous phase, which provides a less greasy feeling in contact with the skin, considering its application in the facial region.

\section{Polarized light microscopy}

The systems obtained show a large number of

TABLE I - Results of the phytochemical characterization of the green tea glycolic extracts. The symbols $(+)$ indicates a positive reaction

\begin{tabular}{lcc}
\hline Reaction & Compound researched & Staining \\
\hline Shinoda's Reaction & Flavonoids & Dark orange \\
Reaction of ferric chloride & Flavonoids & Dark green \\
Reaction with solution of $\mathrm{NaOH}$ & Flavonoids & Brown yellow \\
Reaction with iron salts & Tannins & Transparent blue \\
Reaction with lead acetate & Tannins & Orange with formation of lumps \\
\hline
\end{tabular}




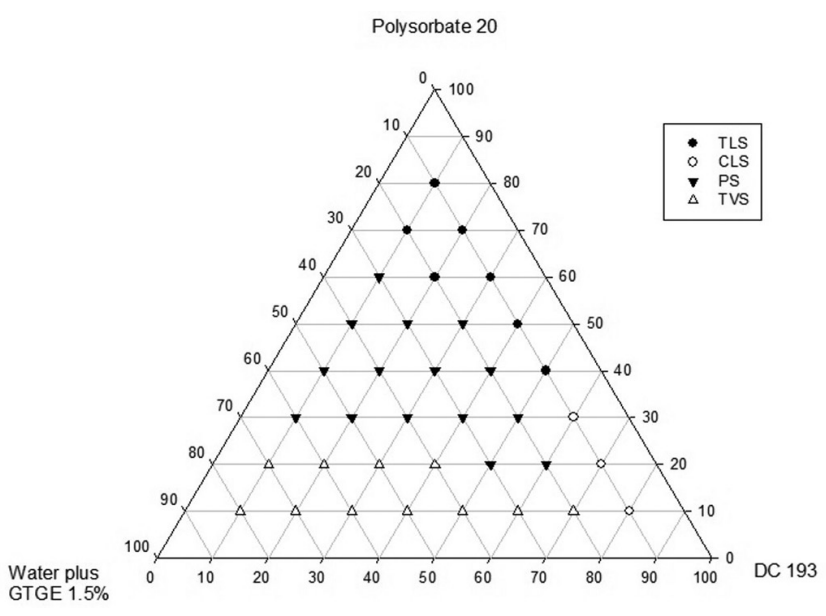

FIGURE 1 - Pseudoternary phase diagram produced by the investigated system using silicone glycol copolymer - DC $193^{\circledR}$, polysorbate 20 , and distilled water with green tea glycolic extracts $1.5 \%$. The symbols indicate: $\bullet$ - transparent liquid system, $\circ$ - cloudy liquid system, $\Delta$ - transparent viscous system and $\nabla$ phase separation.

Maltese crosses, indicating lamellar mesophase. The maintenance of liquid crystal in TLS and TVS was verified 30 days after preparation (Figure 2).

The structure of the lamellar mesophase consists of Maltese crosses, which are formed by surfactant bilayers separated by solvent layers. Systems composed by this structure provide promising drug release control, according to the literature (Bernegossi et al., 2016).

\section{Microbiological quality control}

\section{Estimating the number of viable microorganisms}

The results of the microbial analyses for counting mesophilic aerobic microorganisms (bacteria and fungi) for the studied formulation and their raw materials. The evaluation revealed a microbial load number of contaminating microorganisms on a certain amount of material prior to that material being sterilized) of less than $10 \mathrm{CFU} / \mathrm{mL}$. Such data indicate adequate microbiological quality of the tested products according to official recommendations by the USP 31 . The products (SGCDC $193{ }^{\circledR}$, Polysorbate 20 and GTGE) did not present microbial contamination on the three essays $(<10 \mathrm{CFU} / \mathrm{g})$.

\section{Validation of the method for estimating the number of viable microorganisms}

In a test validation, $80 \%$ of microorganisms were recovered in both dilutions. In accordance to the official recommendation by USP 31 , the high
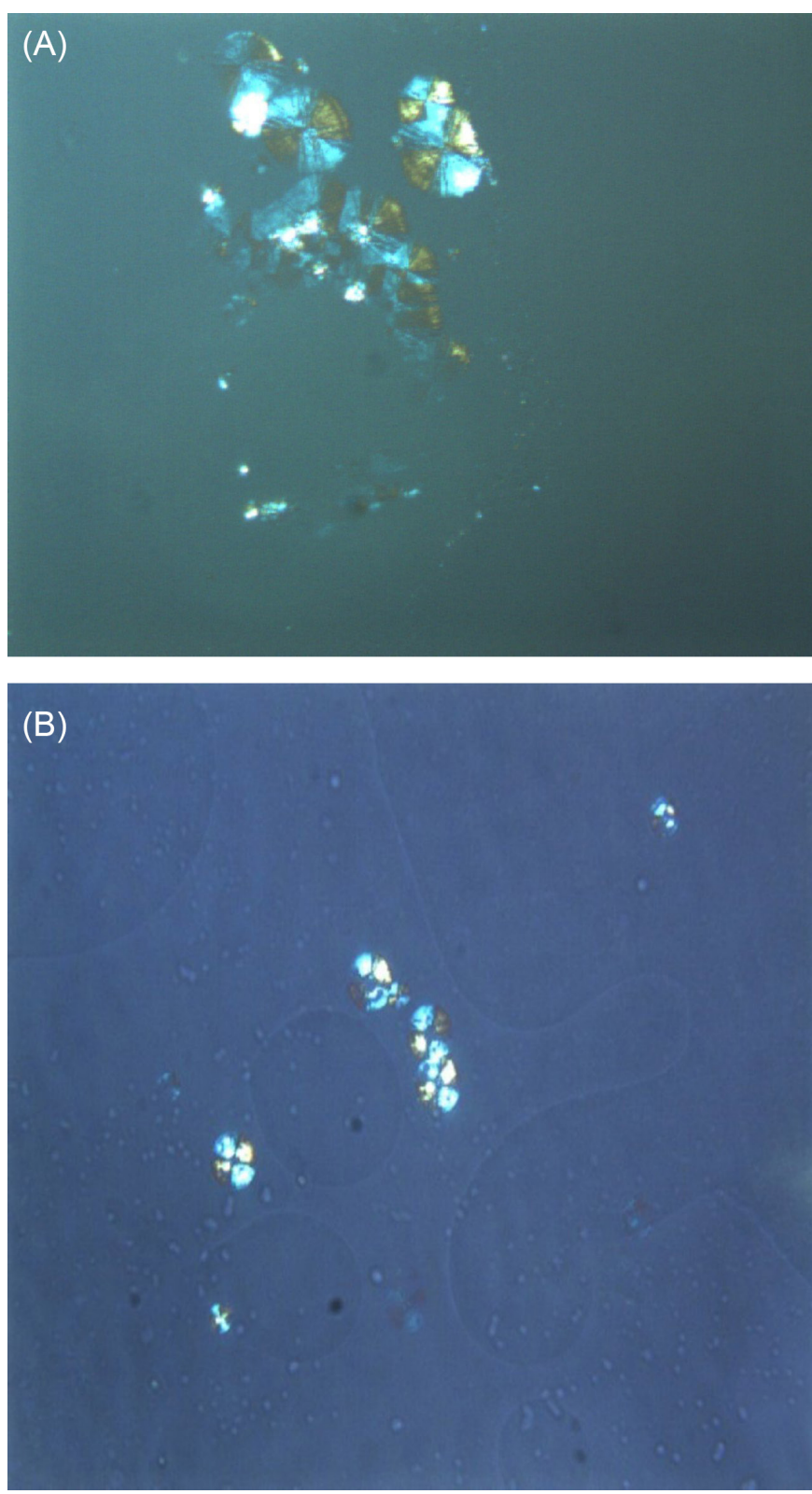

FIGURE 2 - Photomicrographs of samples by polarized light microscopy, where: (A) transparent liquid system and (B) transparent viscous system.

index of microorganism recovery (higher than 75\%) in microbiological validation tests shows the absence of antimicrobial activity. Hence, the selected method for enumerating challenging microorganisms can be considered validated.

\section{Research of Salmonella spp. and E. coli}

No growth was observed after performing the assays for Salmonella spp. and E. coli, thus ensuring the quality of the formulations. 


\section{Research of $S$. aureus and $P$. aeruginosa}

No growth was observed after performing the assays for $S$. aureus and $P$. aeruginosa, thus ensuring the safety of the formulations. The results obtained for all the formulations suggest that they were approved for use regarding their microbiological aspects.

Cosmetic products are divided into two different categories: (1) products specifically for children under three years of age or for use in the eye area or on mucous membranes and (2) other products (Hugbo, Onyekweli, Igwe, 2003). For category 1 products, the total viable counts for mesophilic aerobic microorganisms must not exceed $100 \mathrm{CFU} / \mathrm{g}$ in $0.5 \mathrm{~g}$ of the product. Furthermore, the pathogenic microorganisms $P$. aeruginosa, $S$. aureus, E. coli, and Salmonella spp. must not be detectable in $0.5 \mathrm{~g}$ of the product. For category 2 products, total viable counts must not exceed $1000 \mathrm{CFU} / \mathrm{g}$ in $0.1 \mathrm{~g}$ and the pathogens mentioned above must not be detectable in $0.1 \mathrm{~g}$ of the product (USP, 2008).

Formulations for use in regions close to the eyes were prepared in this study. Hence, these products were classified as type-1 products, which the level of acceptable contamination is lower. It was observed that the formulations remained below the limits required by the USP 31 and resolution of Brazil (USP, 2008; ANVISA, 1999). In addition, they did not facilitate the growth of pathogens in the culturing assays, confirming the microbiological quality of the formulations.

\section{CONCLUSIONS}

In conclusion, it was possible to obtain LCSs with components chosen by the development of the phase diagram in a concentration ratio suitable for topical formulations. The region studied (50\% of surfactant, $5 \%$ of SGC - DC $193^{\circledR}$, and $45 \%$ of the aqueous phase) showed liquid-crystalline phases of the lamellar type. The formulation and raw materials analyzed did not present microbial contamination, as evidenced by estimating the number of viable microorganisms $(<10 \mathrm{CFU} / \mathrm{g})$ and by culturing pathogens.

\section{ACKNOWLEDGMENTS}

The authors are grateful to FAPESP (São Paulo Research Foundation) Process 2010/17037-6; CNPq (National Counsel of Technological and Scientific Development) and PADC/ FCF (Support Program for Scientific Development at the Faculty of Pharmaceutical Sciences) - UNESP, Brazil.

\section{REFERENCES}

AGÊNCIA NACIONAL DE VIGILÂNCIA SANITÁRIA. ANVISA. Guia de estabilidade de produtos cosméticos. Brasília: ANVISA, 2004.

AGÊNCIA NACIONAL DE VIGILÂNCIA SANITÁRIA. ANVISA. Resolução RDC, $\mathrm{n}^{\circ}$ 481, de 23 de setembro de 1999. Estabelece os parâmetros de controle microbiológico para os produtos de higiene pessoal, cosméticos e perfumes. Brasília, 1999.

AOUADA, F.A.; MOURA, M.R.; RUBIRA, A.F.; MUNIZ, E.C.; FERNANDES, P.R.G.; MUKAI, H.; SILVEIRA, A.C.F.; ITRI, R. Birefringent hydrogels. Birefringent hydrogels based on PAAm and lyotropic liquid crystal: Optical, morphological and hydrophilic characterization. Eur. Polym. J., v.42, n.10, p.2781-2790, 2006.

AYANNIDES, C.A.; KTISTIS, G.G. Stability estimation of emulsions of isopropyl myristate in mixtures of water and glycerol. J. Cosmet. Sci., v. 53, n.3, p.165-73, 2002.

BARTU゚NĚK, V.; JUNKOVÁ, J.; ŠUMAN, J.; KOLÁŘOVÁ, K.; RIMPELOVÁ, S.; ULBRICH, P.; SOFER, Z. Preparation of amorphous antimicrobial selenium nanoparticles stabilized by odor suppressing surfactant polysorbate. Mater. Lett., v.152, p.207-209, 2015.

BERNEGOSSI, J.; CALIXTO, G.M.F.; SANCHES, P.R.S.; FONTANA, C.R.; CILLI, E.M.; GARRIDO, S.S.; CHORILLI, M. Peptide KSL-W-loaded mucoadhesive liquid crystalline vehicle as an alternative treatment for multispecies oral biofilm. Molecules, v.21, n.1, p.1-14, 2016.

BOU-CHACRA, N.A.; GOBI, S.S.; OHARA, M.T.; PINTO, T.J.A. Antimicrobial activity of four different dental gel formulas against cariogenic bacteria. Rev. Bras. Ciênc. Farm., v.41, n.3, p.323-31, 2005.

BRAZILIAN PHARMACOPOEIA. 5. ed. v. 5.5.3 - v. 5.5.3.1.2. Brasília: Anvisa, 2010. p.240.

CALIXTO, G.M.F.; BERNEGOSSI, J.; SANTOS, B. F.; CHORILLI, M. Nanotechnology-based drug delivery systems for treatment of oral cancer: a review. Int. J. Nanomed.., v.9, p. 3719-3735, 2014. 
CALIXTO, G.M.F.; VIEIRA, D.C.M.; FIÚZA, T.F.M.; SALGADO, H.R.; CHORILLI, M. Antibacterial activity of gels with pomegranate, apricot and green tea glycolic extracts. J. App. Pharm. Sci., v.2, n.12, p.13-16, 2012.

CHORILLI, M.; PRESTES, P.S.; RIGON, R.B.; LEONARDI, G.R.; CHIAVACCI, L.A.; SARMENTO, V.H.V.; OLIVEIRA, A.G.; SCARPA, M.V. Structural characterization and in vivo evaluation of retinyl palmitate in non-ionic lamellar liquid crystalline system. Colloids Surf. B Biointerf., v.85, n.2, p.182-188, 2011.

CHORILLI, M.; PRESTES, P.S.; RIGON, R.B.; LEONARDI, G.R.; CHIAVACCI, L.A.; SCARPA, M.V. Desenvolvimento de sistemas líquido-cristalinos empregando silicone fluído de co-polímero glicol e poliéter funcional siloxano. Quim. Nova, v.32, n.4, p.1036-1040, 2009.

CHORILLI, M.; RIGON, R.B.; CALIXTO, G.; CARTEZANI, P.M.F.; RIBEIRO, M.C.A.P.; POLACOW, M.L.O.; CERRI, P.S.; SARMENTO, V.H.V.; SCARPA, M.V. Rheological Characterization and safety evaluation of non-ionic lamellar liquid crystalline systems containing retinyl palmitate. $J$. Biomed. Nanotechnol., v.12, n.2, p.394-403, 2016.

FORMARIZ, T.P., URBAN, M.C.C.; SILVA JÚNIOR, A.A.S.; GREMIÃO, M.P.D.; OLIVEIRA, A.G. Microemulsões e fases líquidas cristalinas como sistemas de liberação de fármacos. Rev. Bras. Ciênc. Farm., v.41, n.3, p.301-313, 2005.

FRASER, S.; SEPAROVIC, F.; POLYZOZ, A. Cubic phases of thernary amphiphile-wyater systems. Eur. Bioph. J., v.39, n.1, p.83-90, 2009.

GIANETI, M.D.; MERCURIO, D.G.; MAIA CAMPOS, P.M.B.G. The use of green tea extract in cosmetic formulations: not only an antioxidant active ingredient. Dermatol. Ther., v.26, n.3, p.267-271, 2013.

GLORY, A.; JUDIN, J.; VASUDEVAN R, SUMATHI P. Preliminary phytochemical content and antibacterial activity of Ukshi (Calycopteris floribunda Lam.) leaves. J. Med. Plants Stud., v.4, n.2, p.57-59, 2016.

GURSOY, R.; BENITA, S. Self-emulsifying drug delivery systems (SEDDS) for improved oral delivery of lipophilic drugs. Biomed. Pharmacother., v.58, n.3, p.173-182, 2004.
HOSMER, J.; REED, R.; BENTLEY, M.V.L.B.; NORNOO, A.; LOPES, L.B. Microemulsions containing medium-chain glycerides as transdermal delivery systems for hydrophilic and hydrophobic drugs. AAPS PharmSciTech, v.10, n.2, p.589-596, 2009.

HUGBO, P.G.; ONYEKWELI, A.O.; IGWE, I. Microbial contamination and preservative capacity of some brands of cosmetic creams. Trop. J. Pharm. Res., v.2, n.2, p.22934, 2003.

KONEMAN, E.W.; ALLEN, S.D.; JANDA, W.M.; SCHRECKENBERGER, P.C.; WASHINGTON, C.W. Diagnóstico microbiológico. São Paulo: Medsi, 2001. 1465 p.

LEÃO, M.F.M.; DUARTE, J.A.; SCHMITT, E.G.; QUINTANA, L.D.; ZAMBRANO, L.A.B.; ROCHA, M.B.; ZURAVSKI, L.; OLIVEIRA, L.F.S.; MACHADO, M.M. Avaliação da eficiência de extração dos polifenóis de amostras de chá através de métodos domésticos. Eletr. J. Pharm., v.13, n.2, p.82-88, 2016.

MASSARO, R.C.; ZABAGLI, M.S.; SOUZA, C.R.F.; OLIVEIRA, W.P.; DEL LAMA, D.S.; ROCHA-FILHO, P.A. O/W dispersions development containing liquid crystals. Boll. Chim. Farm., v.142, n.7, p.264-70, 2003.

MASSON, D.S.; MORAIS, G.G.; MORAIS, J.M.; ANDRADE, F.F.; SANTOS, O.D.H.; OLIVEIRA, W.P.; ROCHAFILHO, P.A. Polyhydroxy alcohols and peach oil addition influence in liquid crystal formation and rheological behaviour of O/W emulsions. J. Dispersion Sci. Technol., v.26, n.4, p.463-68, 2005.

OLIVEIRA, M.B.; VIEIRA, D.C.M., FIÚZA, T.M.; SALGADO, H.R.N; CHORILLI, M. Microbiological control of moisturizing mask formulation added of hibiscus flowers, assai palm, black mulberry and papaw glycolic extracts. Int. J. Pharm. Pharm. Sci, v.5, n.1, p.342-345, 2013.

OLIVEIRA, T.A.; PAIXÃO, F.G.; PRESTES, O.S.; PIRESDE-CAMPOS, M.S.M.; POLACOW, M.L.O.; CHORILLI, M.; LEONARDI, G.R.; NASCIMENTO, G.G.F. Avaliação da atividade antimicrobiana de sistemas nanoestruturados. Acta Farm. Bonaerense, v.26, p.878-882, 2007. 
OYAFUSO, M.H.; CARVALHO, F.C.; CHIAVACCI, L.A.; GREMIÃO, M.P.D; CHORILLI, M. Design and characterization of silicone and surfactant based systems for topical drug delivery. J. Nanosci. Nanotechnol., v.15, n.1, p.817-826, 2015.

PEREIRA, A.V.; ALMEIDA, T.C.; BELTRAME, F.L.; COSTA, M.E.; GARRIDO, L.H. Determinação de compostos fenólicos em amostras comerciais de chás verde e preto Camellia sinensis (L.) Kuntze, Theaceae. Acta Sci, v.31, n.2, p.119-124, 2009.

PRESTES, P.S.; CHORILLI, M.; CHIAVACCI, L.A.; SCARPA, M.V.; LEONARDI, G.R. Physicochemical characterization and rheological behavior evaluation of the liquid crystalline mesophases developed with different silicones. J. Disper. Sci. Technol., v.31, n.1, p.117-123, 2010.

RODRIGUES, M.J.; NEVES, V.; MARTINS, A.; RAUTER, A.P.; NENG, N.R.; NOGUEIRA, J.M.F.; VARELA, J.; BARREIRA, L.; CUSTÓDIO, L. In vitro antioxidant and anti-inflammatory properties of Limonium algarvense flowers' infusions and decoctions: A comparison with green tea (Camellia sinensis). Food Chem., v.200, n.1, p.322-329, 2016.

SANTOS, O.D.H.; ROCHA FILHO, P.A. Influence of surfactant on the thermal behavior of marigold oil emulsions with liquid crystal phases. Drug Dev. Ind. Pharm., v.33, n.5, p.543-549, 2007.
SENGER, A.E.V.; SCHWANKE, C.H.A.; GOTTLIEB, M.G.V. Green tea (Camellia sinensis) and its functionals properties on transmissible chronic diseases. Scientia Medica, v. 20, n.4, p.292-300, 2010.

SHAIKH, D.; JAMSHED, T.A.; SHAIKH, R. Microbial contamination of pharmaceutical preparations. Pak. J. Pharm. Sci., v.1, n.1, p.61-66, 1988.

SIMÕES, C.M.O. Farmacognosia: da planta ao medicamento. 5.ed. Porto Alegre; Florianópolis: Editora da Universidade UFRGS; Editora da UFSC, 2003.

THE UNITED STATES PHARMACOPEIA. USP. USP 31. The United States Pharmacopeial Convention. Rockville, 2010.

VASCONCELOS, T.Y.L.; MEDEIROS, D.P.F.; NASCIMENTO, A.A. Inhibition of the preservative system of two o/w emulsions by polysorbate 80. I.C.F., v.27, n.4, p.221-225, 2015.

YUN, G.L.; YANG, S. Study on the extraction and in vitro free radical scavenging activity of tea green pigment. J. Food Saf. Qual., v.6, n.12, p.5067-5071, 2015.

Received for publication on $04^{\text {th }}$ May 2015 Accepted for publication on $09^{\text {th }}$ September 2016 